\title{
Święty cesarz i Słowianie Znaczenie ideowe wątku polskiego w Żywocie św. Henryka oraz Miracula Sancti Heinrici
}

Spośród źródeł dokumentujących relacje polsko-niemieckie w XII wieku ciekawym, choć dotąd - wydaje się — rzadko i pobieżnie analizowanym, tekstem jest wykaz cudów (Miracula Sancti Heinrici) ${ }^{1}$ dołączony do Żywota $s ́$ w. Henryka - króla niemieckiego (1002-1024) i cesarza rzymskiego (od 1014 roku), świętego Kościoła katolickiego od połowy XII wieku do chwili obecnej $^{2}$. W dotychczasowych opracowaniach nawiązujących do wspomnianego przekazu zajmowano się głównie wątkami politycznymi w nim zawartymi. Nie ma tam ich jednak zbyt wiele, dlatego treści Miracula Sancti Heinrici nie analizuje się często w pracach historycznych poświęconych epoce i stosunkom kraju Piastów z Rzeszą ${ }^{3}$.

${ }^{1}$ Ex Allis Miraculis Sancti Henrici, Annales, Chronica et historiae aevi Carolini et Saxonici. In: MGH S. T. 4. Hannoverae 1841, s. 814-816; Die Vita sancti Heinrici regis et confessoris und ihre Bearbeitung durch den Bamberger Diakon Adelbert. Ed. M. STUmPF. In: Monumenta Germaniae Historica. Scriptores rerum Germanicarum. Hannover 1999, s. 225-324.

${ }^{2}$ Ostatnia monografia Henryka II: S. Weinfurter: Heinrich II. (1002-1024). Herrscher am Ende der Zeiten. Regensburg 1999.

${ }_{3}$ Wspomniano o nim w pracy: A. Pleszczyński: Przekazy niemieckie o Polsce i jej mieszkańcach $w$ okresie panowania Piastów. Lublin 2016, s. 119, ale analiza w tym wypadku dotyczyła ogólnie kwestii niemieckich opinii o Polsce w okresie panowania Piastów. Z tego powodu wzmianka o miracula św. Henryka musiała być tam potraktowana dość powierzchownie. Najbardziej szczegółowa analiza fragmentu źródła dotyczącego poselstwa biskupa płockiego Wernera do Fryderyka Barbarossy, a także szerzej ujętego wątku biskupstwa płockiego w: C. DeptuŁa: Niektóre aspekty stosunków polsko-niemieckich w XII wieku. W: Polska w Europie. Studia historyczne. Red. H. ZIns. Lublin 1968; C. DeptuŁa: Werner (zm. 1172) biskup 
Miracula Sancti Heinrici staje się jednak źródłem niezwykle interesującym, jeśli potraktujemy ten przekaz jako narrację odzwierciedlającą pewne idee obecne w kręgu dwunastowiecznego duchowieństwa bamberskiego, które możemy uznać za zbiorowego autora interesującego nas utworu. Szczególną uwagę zwraca bowiem zawarty w tekście wątek dotyczący rozprzestrzeniania się kultu św. Henryka II na ziemie słowiańskie Rzeszy, a zwłaszcza przebijająca przez narrację myśl zaszczepienia kultu osoby świętego monarchy również na Polskę. Nie ma żadnych informacji, by formalnie kult ostatniego Ludolfinga został kiedykolwiek zaszczepiony w państwie Piastów, jednak ciekawym problemem wydaje się występująca w Miracula... idea połączenia postaci św. Henryka II nie tylko z będącymi pod władaniem Rzeszy obszarami Słowiańszczyzny, ale także z Polską.

Celem niniejszego artykułu jest dokładniejsze przyjrzenie się wybranym fragmentom Miracula Sancti Heinrici, aby wraz z uwzględnieniem treści całego żywota zastanowić się, w jaki sposób starano się związać postać Henryka II z Polską oraz Słowiańszczyzną i jaki był sens tych zabiegów. Istotne będzie ponadto zanalizowanie, jak został w źródle przedstawiony kraj, w którym próbowano zainicjować kult niemieckiego monarchy.

Wskazane kwestie zostaną rozwinięte następująco. Na początku przedstawione zostaną dwa fragmenty źródła pokazujące cuda, jakie wydarzyły się za pośrednictwem św. Henryka II i jakie miały związek ze Słowianami i z Polską. Dokonana zostanie wstępna analiza przesłania zawartego w tych rozdziałach Miracula... Następnie uzyskane wyniki pokazane zostaną w kontekście historycznym czasów powstania przekazu i naszej wiedzy o relacjach państwa Fryderyka Barbarossy oraz ośrodka kultu św. Henryka w Bambergu z Polską.

Pierwszy fragment to opis cudu uzdrowienia, kolejny opowiada o widzeniu biskupa płockiego Wernera. Zastanowimy się nad wymową ideową wskazanych przykładów źródłowych, w końcu zaś umieścimy treści źródłowe i ich sens $\mathrm{w}$ kontekście historycznym miejsca oraz czasu powstania interesującego nas przekazu.

Płocka. W: Hagiografia polska. Red. R. Gustaw. T. 2. Poznań 1971, s. 513-521. Wątek wspomniany także w: S. TrawKowski: Taberny płockie na przełomie XI i XII wieku. Prz. Hist. 1962, T. 53, z. 3-4, s. 738. Więcej o relacjach polsko-niemieckich w XII w. w: M. Biniaś-Szкopek: Bolesław Kędzierzawy, ksiąze Mazowsza i princeps. Poznań 2009; ostatnio problem został omówiony w pracy: M. Lindner: Aachen - Dobrilugk - Płock. Markgraf Dietrich von der Ostmark, Bischof Werner von Płock und die Anfänge des Zisterzienserklosters Dobrilugk. In: Die Nieder- und Oberlausitz - Konturen einer Integrationslandschaft. Bd. 1: Mittelalter. Hrsg. H.-D. Heimann, K. Neitmann, U. Tresp. Berlin 2013, s. 139-176; zob. także: G. ZimMERMANN: Karlskanonisation und Heinrichsmirakulum. Ein Reliquienzug der Barbarossazeit von Aachen über Dobrelug/Lausitz nach Ptock. „Bericht des Historischen Vereins von Bamberg“ 1966, Vol. 102, s. 127-148. 
Najpierw zatem przyjrzyjmy się doniesieniu o cudownym uzdrowieniu, jakie miało się dokonać w Merseburgu ${ }^{4}$. Opowieść rozpoczyna się wiadomością, że przy kościele św. Piotra znalazł się pewien niewidomy Słowianin. Słysząc dobiegające $\mathrm{z}$ wnętrza świątyni radosne odgłosy ludzi cieszących się z dokonanego właśnie uzdrowienia chorego, człowiek ów nie zrozumiał zrazu przyczyn tego uniesienia. Uświadomiono mu więc, że to łaska Boska zażegnała ciężką chorobę, a stało się to w wyniku wstawiennictwa Henryka II. Słowianin również zapragnął odzyskać wzrok. Wahał się jednak prosić o to świętego, ponieważ wiedział, że był on Niemcem, a on sam zaś czuł się, najwidoczniej, obcy i w stosunku do Niemców, i do ich świętego. Gromadzący się w miejscu cudu tłum rozwiał wątpliwości ślepca, tłumacząc mu, że wstawiennictwo cesarza nie ogranicza się do jednego narodu, zatem także i on może doświadczyć nadprzyrodzonej opieki Henryka II. Dalszy bieg historii przyjął już nieszczególnie zaskakujący nas obrót. Niewidomy pokornie oddał cześć świętemu w kościele i modlił się, leżąc krzyżem przed jego relikwiami, co w niedługim czasie poskutkowało odzyskaniem wzrokus.

Niejako pomiędzy wierszami przekazu da się wyczytać opinię, że ów człowiek nie był wyznawcą Chrystusa. Ponadto nawet pobieżne zapoznanie się z relacją pozwala stwierdzić, że głównym przesłaniem tekstu Miracula ... było podkreślenie mocy i uniwersalnego charakteru świętości ostatniego Ludolfinga, która miała kierować się ku Słowianom, będącym jeśli nawet nie poganami, to na pewno „gorszymi chrześcijanami”' Można oczywiście mniemać, że głównymi adresatami przesłania zapisanego w źródle byli jedynie Słowianie łużyccy osiadli w okolicach Merseburga, ale drugi z cudów (o którym nieco

${ }^{4}$ „Est aecclesia parriochialis aecclesiae beati Petri in veteri castro contigua; iuxta quam sedens cecus quidam, audivit concentum popularium in reparatione cuiusdam egri devotissime congratulantium. Erat autem hic de terra et de genere Sclavorum; quibus simplicitas vel irrationalitas pravitate quadam ingenii naturalis est, adeo ut, vix vel teunem fidei videnatur habere scintillam. Causam igitur huius concentus a circumstantibus requisivit. Cui cum pro sanatione languentis haec fieri indicatum fuisset, ait: Iste Heinricus Teutonicus cum sit, solis Teutonicis gratie sue prestat subsidium; mihi vero gentisque mee hominibus nihil umquam beneficii contulit. In risum ergo qui aderant excitantur. Quidam vero sanioris consilii, ut aecclesiam petat pro salute sua rogaturus, adhortantur. Ductus itaque, ubi reliquie beati confessoris servabantur, humo prosternitur; et paulo post pietatem Teutonici Sclavus ipse quam negari sibi querebatur gratiam experitur. Ceperunt enim ab occulis eius albedines in modum squamarum avelli, opatumque lucis suffragium in eo redintegrari. Unde gens illa, que ut dixi, rustica simplicitate et fidei pusillanimitate se sperni arbitrabatur, hoc beneficio fiducia speque resumpta, ultra omnes beatum Heinricum studio devociori venerabatur" — Ex Allis Miraculis..., s. 815.

5 „Ceperunt enim ab occulis eius albedines in modum squamarum avelli, opatumque lucis suffragium in eo redintegrari" — tamże.

6 A. Pleszczyński: Niemcy wobec pierwszej monarchii piastowskiej (963-1034). Narodziny stereotypu. Postrzeganie i cywilizacyjna klasyfikacja władców Polski i ich kraju. Lublin 2008, s. 38-42; zob. także: S. RosıK: Conversio gentis Pomeranorum. Studium świadectwa o wydarzeniu (XII wiek). Wrocław 2010, s. 362-367. 
dalej), wraz z innymi treściami Miracula... i samego żywota świętego władcy, uświadomi nam, że chodziło również o coś więcej. Zanim jednak przytoczymy kolejny fragment źródła, by rozważyć szerszą perspektywę jego myśli przewodniej, zastanowimy się jeszcze nieco dokładniej nad znaczeniem przedstawionej tu opowieści.

Połączenie motywu uzdrowienia niewidomego z nawróceniem nie było przecież oryginalne. Opowieści o cudach odgonienia choroby czy przywrócenia pełni sprawności cieszyły się w średniowieczu dużą popularnością, a ich archetypem była, jak się wydaje, przypowieść Ewangelii wedtug św. Jana (J 9,1-11)7. W wieku XII pojawiła się też legenda o ślepocie św. Longinusa, centuriona rzymskiego, który miał przebić bok Ukrzyżowanego i wówczas krew Chrystusa, która obmyła mu oczy, nie tylko przywróciła im pełnię sprawności, ale i sprawiła, że dawny poganin stał się zagorzałym chrześcijaninem, w końcu zaś świętym ${ }^{8}$. Powszechnie znana historia łączyła zatem ślepotę z pogaństwem, co przecież ma archetypiczny związek z niemieckimi opiniami ${ }^{9}$ dotyczącymi Słowian w średniowieczu, które podkreślały mocne przywiązanie tego ludu do słowiańskich religii.

Topos nawróconego ślepca odnajdziemy także w tekstach powstałych na obszarze samej Słowiańszczyzny. Pojawił się on przecież w Gallowej opowieści o Mieszku I ${ }^{10}$. Według kronikarza syn Siemomysła miał pozostawać ślepcem do siódmego roku życia, dopiero podczas postrzyżyn odzyskał wzrok. Zdaniem Galla książęcy „mędrcy” uznali to za znak szczególny, który stanowił przede wszystkim o przyszłej roli Mieszka jako chrystianizatora. Kronikarz mówi wprost: ,[...] ślepota oznaczała, iż Polska przedtem była ślepa - lecz odtąd ma być przez Mieszka oświeconą, wywyższoną [...]”, i dalej: „Zaiste ślepa była dotąd [Polska] nie znając ani czci prawdziwego Boga ani zasad wiary"11. Istnieje ponadto również ruska tradycja, według której Włodzimierz Wielki przed chrztem miał oślepnąć, ale namawiająca go do konwersji Anna Porfirogenetka wyjaśniła mu, że odzyska wzrok, gdy tylko jego oczu dosięgnie woda chrzcielna ${ }^{12}$.

Nie ma potrzeby mnożenia przykładów tej powszechnie występującej w świecie chrześcijańskim opowieści. Sam fakt jednak umieszczenia w tak

${ }^{7}$ Biblia Sacra. Vulgate Editionis. Ed. A. Colunga, L. Turado. Madrid 1995.

${ }^{8}$ G. Malcolm: The Holy Grail: Its Origins, Secrets \& Meaning Revealed. London 1994, s. 51.

${ }^{9}$ Więcej w: A. Pleszczyński: Przekazy niemieckie o Polsce...

10 Więcej o wątku ślepoty Mieszka w: P. Wiszewski: Struktura, fabuła i historia. Wokót opowieści o odzyskaniu wzroku przez Mieszka. „Biuletyn Polskiej Misji Historycznej” 2009, T. 5 , s. $45-64$.

11 Anonim tzw. Gall: Kronika polska. Przekł. oprac., wstępem i przypisami opatrzył M. Plezia. Przeł. R. Grodecki. Wrocław 1982, s. 16-17.

${ }_{12}$ Powieść minionych lat. Charakterystyka historycznoliteracka. Przeł. F. SiELICKI. Kraków 1968, s. 111. 
znanym schemacie fabularnym uzdrowienia poganina i przyjęcia przez niego wiary osób św. Henryka II i Słowianina miał swój sens historyczny, coś oznaczał. Usunięcie „pogańskich łusek” z oczu niewierzącego zasugerowane w miraculis nie było niby topicznie niczym szczególnym, natomiast znamienne jest dopiero włączenie do tego schematu fabularnego Słowianina. Uzdrowiony ślepiec dołączył do grona wyznawców kultu św. Henryka, tym samym stając się w pewnym sensie jego poddanym. Miało to jednak, jak się wydaje, szersze znaczenie.

Zacznijmy od kwestii bardziej ogólnych. Najpierw zatem zwróćmy uwagę, że na naszkicowane tu ukazanie charakteru Słowianina w analizowanej narracji potężny wpływ wywierały stereotypy funkcjonujące od bardzo dawna w piśmiennictwie europejskim ${ }^{13}$. Od antyku przecież popularnym zabiegiem stosowanym przez wielu autorów było przypisywanie barbarzyństwa ludom zamieszkującym północne, położone powyżej biegu Dunaju i na wschód od Renu, obszary kontynentu ${ }^{14}$. Autorzy średniowieczni przejęli tę manierę od Greków i Rzymian. W przekazach niemieckich, zwłaszcza wczesnośredniowiecznych, topicznie lokowano Słowian (podobnie zrazu i Skandynawów) na obszarze „barbarzyńskiej Północy", a więc na terenach kojarzonych z pogaństwem ${ }^{15}$.

W kontekście naszkicowanego wcześniej przekazu Miracula... ważna jest jeszcze jedna kwestia. Otóż w tamtym czasie utrwalała się pewna ideologia władzy, według której każdy lud powinien posiadać swojego niebiańskiego patrona i wspomożyciela, najlepiej pochodzącego z rodu dynastycznego. W ten kontekst właśnie trzeba wpisywać liczne kanonizacje władców, jakie wówczas miały miejsce $^{16}$. W przypadku wyniesienia na ołtarze Henryka II sprawa jest bardziej złożona. Rzesza, i poszczególne jej ludy, posiadała już kilku patronów. Wiemy przecież o św. Maurycym w Magdeburgu, św. Emmeramie w Ratyzbonie. Powszechnie znany jest związek kultu św. Szczepana, również św. Wawrzyńca, z potrzebami politycznymi (i pewnie ideowymi) władców niemieckich ${ }^{17}$. Warto

13 Więcej w: A. Pleszczyński, J. Sobiesiak, K. Szejgiec, M. Tomaszek, P. Tyszka: Historia communitatem facit. Struktura narracji tworzacych tożsamości grupowe $w$ średniowieczu. Wrocław 2016, s. 189-206.

${ }^{14}$ A. Pleszczyński: Przekazy niemieckie o Polsce..., s. 173.

15 A. Pleszczyński: Niemcy..., s. 180.

${ }^{16}$ Wyjątek stanowią tutaj najwcześniejsze przypadki świętych władców. Jak wskazuje G. Klinczay, trudno doszukiwać się motywów politycznych w kanonizacji św. Zygmunta czy św. Radegunda. Uświęcanie postaci władców z czasów Merowingów nie przyniosło skutków politycznych. Inaczej kwestia ta wyglądała w anglosaskim modelu królestwa oraz w późniejszych kanonizacjach władców niemieckich. Zob. G. KlinczaY: Holy Rulers and Blessed Princesses. Dynastic Cults in Medieval Central Europe. Cambridge 2002, s. 78; zob. także: E. Hoffmann: Die heiligen Könige bei den Angelsachsen und den skandinavischen Völkern. Königsheiliger und Königshaus. Neumünster 1975.

${ }_{17}$ Zob. zbiór: Politik und Heiligenverehrung im Hochmittelalter. Hrsg. J. Petersohn. Sigmaringen 1994, zwłaszcza zamieszczony tam tekst: J. Petersohn: Kaisertum und Kultakt in der Stauferzeit, s. 101-146. 
jednak pamiętać, że także w kwestii kultu istniały mody - z czasem moc dewocji kierowanej ku jakiemuś świętemu ulegała osłabieniu, ponieważ przecież z określoną postacią ze świata nadprzyrodzonego łączono pewne potrzeby doczesne.

Zawsze zatem, jeśli zajmujemy się szeroko pojętą hagiografią, powinniśmy starać się zrozumieć, jakie było społeczne i polityczne tło wykreowania nowego kultu oraz kto za jego pomocą chciał coś osiągnąć i urzeczywistnić. W przypadku kreacji dewocji św. Henryka II, której popularyzacja nastąpiła w 2. poł. XII wieku, trzeba doszukiwać się różnych przyczyn zjawiska i starać się związać je z sytuacją polityczną w Rzeszy i wokół niej. Oczywistością jest, że ośrodek w Bambergu, którego założycielem był Henryk II, zajmował się sprawą kanonizacji swojego dobrodzieja ${ }^{18}$. Wiemy jednak ponadto, że interesował się tą kwestią również Fryderyk Barbarossa, który nie tylko starał się propagować kult Karola Wielkiego mający szczególne znaczenie na dawnych obszarach frankijskich, ale też włączył do swojej polityki propagandowej św. Henryka, który mógł dostarczyć mu wsparcia ideowego na Wschodzie.

Istotne jest $\mathrm{w}$ kontekście przedstawionego problemu to, że Polska nie posiadała własnego świętego dynastycznego, a pozycja św. Wojciecha jako patrona kraju była wydatnie osłabiona w wyniku konfliktu z Pragą, w której kościele katedralnym miało znajdować się całe jego ciało, wraz z głową. Zdaniem hierarchów gnieźnieńskich zaś głowa świętego miała być przechowywana $\mathrm{w}$ ich archikatedrze, gdzie cudownie przetrwała najazd Brzetysława w roku 1039 i złupienie świątyni, wraz z zabraniem relikwii. Miarę pewnego skandalu powiększał fakt, że i Węgrzy w Ostrzyhomiu mieli posiadać głowę św. Wojciecha ${ }^{19}$. Tereny Polski mogły się więc jawić w oczach Niemców jako obszar nieładu religijnego i ziemia wymagająca pewnego rodzaju ,sakralnego zagospodarowania". Kult Henryka II miałby zatem w sposób naturalny rozpowszechnić się także i tam, zapewniając mieszkańcom kraju nadprzyrodzoną opiekę, której byli pozbawieni albo która mogła uchodzić za słabą.

W kontekście ówczesnej sytuacji politycznej Polski niezwykle interesująca jest kolejna wzmianka o świętej mocy Henryka II skierowanej ku ludności słowiańskiej, opowiadająca o poselstwie biskupa płockiego Wernera do Fryderyka Barbarossy. Przekaz rozpoczyna krótki opis Polski jako państwa bardzo górzystego i błotnistego, pełnego bezdroży — niecywilizowanego ${ }^{20}$,

${ }^{18}$ R. Michalowski: Klasztor prywatny w Niemczech IX - XII w. jako fakt religijny i społeczny. (Wybrane zagadnienia). W: Polska - Niemcy w średniowieczu. Materiały z konferencji naukowej zorganizowanej przez Instytut Historii UAM w dniach 14-16 XI 1983 roku. Poznań 1986, s. $46-66$.

19 Sprawa omówiona została szerzej w: C. Deptula, A. Witkowska: Wzorce ideowe zachowań ludzkich. W: Polska zjednoczona i dzielnicowa. Red. A. GieyszTor. Warszawa 1972, s. 148.

${ }^{20}$ „Magis saltuum ae palludum invis” — Ex Allis Miraculis..., s. 814. 
którego to mieszkańcy mieli dopuścić się buntu przeciw władcy Rzeszy. Gdy jednak zdali sobie sprawę z potęgi armii, jaką zebrał monarcha niemiecki, „książę tej ziemi i cały jego lud zostali dotknięci strachem, ponieważ [...] siebie widzieli jako nierównych i nieobeznanych w doświadczeniu walki" ${ }^{21}$. Aby uniknąć porażki, wysłali więc poselstwo do Fryderyka. Do wykonania tego zadania został wybrany biskup diecezji płockiej Werner. Duchowny dotarł do Akwizgranu, gdzie przebywał wówczas Barbarossa, którego zajmowała wtedy sprawa kanonizacji Karola Wielkiego. Źródło nie podaje, jaka była treść poselstwa, jednakże musiało ono wywrzeć na Fryderyku wielkie wrażenie. Biskupowi nie dość, że udało się zapobiec najazdowi na Polskę, ale otrzymał również relikwie św. Henryka II oraz inne dary (jak okaże się w dalszej części narracji, mowa tutaj o relikwiach św. Zygmunta). Niezwykłość tego wydarzenia powiększa fakt, że w trakcie translacji relikwii zdarzyła się niecodzienna sytuacja. W drodze powrotnej poselstwo rozbiło obóz w lesie, znajdującym się według źródła na obszarze między Łużycami a granicami Polski ${ }^{22}$. We śnie biskup ujrzeć miał postać odzianą w szatę królewską, z berłem w ręku, kierującą do przerażonego duchownego następujące słowa: „Czy w tym szerokim pustkowiu snem dałeś się przygnieść? A że mnie ze sobą masz, to nie wiesz? Ja jestem Henryk, fundator kościoła bamberskiego, który w czasie, gdy żyłem, zasłużyłem sobie u Boga na nagrodę nieśmiertelności. W tym miejscu, w którym leżysz, kościół imieniu mojemu, jak czas pozwoli, zbuduj i wiedz, że bez wątpienia z czasem boska służba w nim będzie trwała" ${ }^{23}$. Kraina, w której doszło do objawienia, nie obfitowała jednak w kamienie potrzebne do budowy świątyni pw. św. Henryka II, której od biskupa płockiego domagała się zjawa. Gdy poselstwo wyruszyło na poszukiwanie odpowiedniego budulca, wydarzył się natomiast kolejny cud. Werner przypadkiem wbił kij — baculus — w kopiec ziemi, a w nim odnalazł przygotowane już do budowy ciosy kamienne. Dzięki temu w miejscu widzenia mógł niemal od razu powstać kościół (a następnie klasztor) ${ }^{24}$,

${ }^{21}$ „Cumque, indicta generali expedicione copiosus a diversis regui partibus coiturus esset exercitus principes terre illius et omnis populus timore corcepti, quippe qui regni vires contra se, commoveri se autem impares et inexpertos pericie beli videbanta" — tamże. Tłumaczenia cytatów obcojęzycznych - M.N.

22 „Quod Zurbie ac Polonie terminis interiacet” — tamże, s. 815.

${ }^{23}$ „Quod in hac rasta solitudine somno deprimeris? Me tectum nesciens geris. Et dum ille perterritus quisnam esset interrogaret respondit: Ego sum Heinricus, Bambenbergensis fundator aecclesiae; qui in temporalis vitae cursu immortalitatis compendium a Domino promerui. In eo ergo quo taces loco aecclesiam nomini meo, prout tempus permittit, construe, sciens procul dubio processu temporis divinum in eo servicium augmentari" — tamże.

${ }^{24} \mathrm{Na}$ ogół uważa się, że chodzi tu o echo legendy założycielskiej klasztoru cysterskiego w Dobrymługu (Duberlug) — zob. M. Lindner: Aachen — Dobrilugk — Plock..., s. 139; zob. także: S. Rosık: Die Christianisierung der slawischen Stämme auf dem heutigen Gebiet der Lausitz. In: Die Nieder- und Oberlausitz..., s. 57-62. 
który ukazał światu moc św. Henryka II i tym samym mógł zwiększyć rzeszę jego wyznawców ${ }^{25}$.

Zaprezentowane doniesienie kończy wątki słowiańskie w zbiorze cudów św. Henryka II. Wypada teraz zastanowić się nad znaczeniem przedstawionych w źródle treści. Zauważmy zatem jeszcze raz, że naszkicowaną sekwencję wydarzeń rozpoczyna krótki opis państwa Piastów. Autor wskazuje tam, że Polska jest krajem górzystym, pełnym bezdroży i mokradeł. Krótko rzecz ujmując: jest to terytorium nieprzystępne dla ludzi, niecywilizowane. Wtórują tym tezom w tekście Miracula... stwierdzenia, że Polacy są ludem buntowniczym i dzikim, pragnącym zrzucić jarzmo cesarskie ${ }^{26}$. W samym zaś żywocie, na jego początku, uwypuklono, że zasługą Henryka II było ucywilizowanie Polski, podobnie Czech i Moraw, które to kraje rzekomo monarcha niemiecki miał podbić i włączyć w granice swojego władztwa ${ }^{27}$.

${ }^{25}$ „Hoc quod subiungo, ipso de quo dicturus sum episcopo referente, Deo teste cognovi. Cum Polonia imperii iugum utpote gens rebelis et effera et magis saltuum ae palludum invis quam virium robore confisa, de cervice sua niteretur executere, ad reprimendam cuis contiumatiam gloriosus imperator Friderien animum intendit. Cumque, indicta generali expedicione copiosus a diversis regui partibus coiturus esset exercitus principes terre illius et omnis populus timore corcepti, quippe qui regni vires contra se, commoveri se autem impares et inexpertos pericie beli videbanta, ad placandam regis iram legatos mittentes iterata subiectione prioris discidii errorem corrigere omnimodis promittebant. Ad hoc igitur negocium reverende persone mireque prudentie episcopum Plocensis aecclesiae Wernherum nomino eleregunt cumque cum donis regiam magnificentiam decentibus ad imperatorem, Aquisgrani morantem et ossa Karoli magni levata in thecis auro gemisque confectis recondendtem, direxerunt. A quo diu repulsus, tandem interventu principium in gratiam est receptus legationeque ad votum peracta, cum reliquiis sancti Heinrici aliisque donis ab imperatore perceptis rediit; et in nemore, quod Zurbie ac Polonie terminis interiacet. mediante iam die, tenoria figi precepit. Cumque post reflectionem fessos ex itinere artus quieti dedisset, quidam in somno regio veste circumamictus et dextra sceptrum gerens illi astitit, hisque verbis eum allocutus ait: Quod in hac rasta solitudine somno deprimeris? Me tectum nesciens geris. Et dum ille perterritus quisnam esset interrogaret respondit: Ego sum Heinricus, Bambenbergensis fundator aecclesiae; qui in temporalis vitae cursu immortalitatis compendium a Domino promerui. In eo ergo quo taces loco aecclesiam nomini meo, prout tempus permittit, construe, sciens procul dubio processu temporis divinum in eo servicium augmentari. Surgit igitur episcopus, statimque per famulantium sibi manus certatim ruentibus lignis, in modum habilem fecit aecclesiam. Sed de lapidum penuara qui ibidem audivi non videri consueverant, dum anxius inter frutecta circuiret episcopus, casu baculum quem ferebat in congestum terrae cumulum figens, lapidum copiam in similitudinem quadratorum reperit; sieque altare componens, Dei et beati Heinrici sanctique Sigismundi regis nomine dedicavit. Ubi nunc multis astipulantibus maior aecclesia construitur ae monachilis profesionis ordo inchoatur; quodque ille predixerant, iam impleri videtur. Hac igitur occasione nomen beati Heinrici apud illas nationes in veneratione cepit haberi” — Ex Allis Miraculis..., s. 815.

${ }^{26}$ „Cum Polonia imperii iugum utpote gens rebelis et effera” — tamże, s. 814.

${ }^{27}$ Zgodnie z narracją zawartą w żywocie Henryk II miał odnowić i wyposażyć biskupstwo w Merseburgu, by następnie podjąć wojnę przeciw Słowianom - Polakom i Czechom, którzy niszczyli wschodnie tereny królestwa. Więcej o wstępie do Żywota św. Henryka w: A. Pleszczyński: Przekazy niemieckie o Polsce..., s. 120. 
Zarazem jednak autor Miracula... wskazuje na to, że ludność Polski ma „małe zaufanie w sile zbrojnej”28. Dzicy mieszkańcy państwa Piastów buntowali się przeciw właściwemu władcy, jednak działali bezmyślnie, ponieważ nie wzięli pod uwagę swojej słabszej przecież pozycji militarnej. Mieszkańcy Polski w ujęciu autora Miracula... byli zatem ludem nie tylko wichrzycielskim, lecz również cechowali się dużą nierozwagą i lekkomyślnością. Cechy te zaś były topicznymi przymiotami wszystkich ludów uważanych za barbarzyńskie, zwykle utożsamianych z pogaństwem.

Dzięki temu zabiegowi dość łatwo udało się uzasadnić w narracji reakcję cesarską na wspomniany rzekomy bunt. Polacy widzieli siebie jako „nierównych i nieobeznanych w doświadczeniu walki”, poselstwo zaś wysłali „dla przebłagania gniewu, aby w ten sposób, ponownym poddaństwem obiecać naprawę błędu wcześniejszego porzucenia [zależności]"29. Sytuacja przedstawiona $\mathrm{w}$ tekście przekazu jest zatem prosta: zbuntowany lud zgodnie ze swoją naturą nie umiał ocenić konsekwencji swego nieposłuszeństwa, w obliczu zagrożenia wycofał się więc i wysłał poselstwo.

Werner otrzymał relikwie stosunkowo niedawno kanonizowanego niemieckiego władcy, by przywieźć je do Polski ${ }^{30}$. Translacja świętych szczątków umożliwiała powstawanie nowych miejsc kultu. Sytuacja, w której przedstawiciel zagrożonego najazdem kraju otrzymuje od niedoszłego najeźdźcy prezent tak cenny jak fragment świętego ciała, pełni w fabule utworu niezwykle ważną funkcję. Wobec tego podarunek dla księcia polskiego byłby dość jasną próbą zaszczepienia kultu niemieckiego władcy na ziemie polskie. Byłby gdyż brak jakichkolwiek dowodów na powstanie w tym okresie w Polsce ośrodków kultu Henryka II. Autor miraculum podaje jednakże w swojej relacji przykład miejsca, które doprowadziło do uznania świętości cesarza przez okoliczne ludy. Mowa tutaj o lesie, który „quod Zurbie ac Polonie terminis interiacet" ${ }^{\prime 3}$. W miejscu tym płocki biskup doświadcza widzenia we śnie. Nie bez przyczyny Werner nie poznaje od razu pojawiającej się przed nim postaci. Daje to pole do autoprezentacji Henryka II. Jest to istotne, gdyż w ten sposób w treść przekazu zostaje wpleciony właściwy obraz świętego cesarza. Henryk sam siebie definiuje jako fundatora kościoła bamberskiego i nie padają w tym miejscu żadne inne tytuły. Henryk II nie określa siebie jako cesarza

28 „Quam virium robore confisa” — Ex Allis Miraculis..., s. 814.

29 „Principes terre illius et omnis populus timore corcepti, quippe qui regni vires contra se, commoveri se autem impares et inexpertos pericie beli videbanta, ad placandam regis iram legatos mittentes iterata subiectione prioris discidii errorem corrigere omnimodis promittebant" - tamże, s. 815.

${ }^{30}$ Więcej o roli relikwii na ziemiach polskich: M. STARnAwsKa: Świętych życie po życiu. Relikwie w kulturze religijnej na ziemiach polskich $w$ średniowieczu. Warszawa 2008. Także: A. Guriewicz: Problemy średniowiecznej kultury ludowej. Warszawa 1987.

${ }^{31}$ Ex Allis Miraculis..., s. 815. 
i władcę, co wiązałoby w sposób zbyt oczywisty jego postać z doczesnym panowaniem. Najważniejszą informacją dla odbiorcy miraculum ma być fakt, że dzięki Henrykowi II funkcjonuje kościół bamberski. Jest to zabieg wyjątkowo logiczny, jeśli weźmiemy pod uwagę oficjalne motywy, które doprowadziły do wyniesienia Henryka II na ołtarze. To poprzez zasługi, jakie oddał Kościołowi podczas swoich rządów, ostatni z Ludolfingów mógł zostać uznany za świętego. Fundacja Bambergu stanowiła najbardziej efektowny argument świadczący o aprobacie dokonań cesarza przez Kościół.

Wyeksponowana rola kościoła bamberskiego jako ośrodka, z którego kult miał przenikać na Wschód, jest nie bez znaczenia dla analizy tekstu miraculum. Bamberg przez wiele lat stanowił jeden z poważniejszych ośrodków nawracających Słowian, również ośrodków misyjnych ${ }^{32}$. Naturalne powiązania między niemieckim klerem z Płocka a bamberskim zakonem benedyktynów z pewnością rzutowały na położenie Wernera na scenie politycznej ${ }^{33}$. Związki mię-

${ }^{32}$ Historia relacji pomiędzy Słowiańszczyzną (z naciskiem na Polskę) a terenami wschodniej Frankonii sięga czasów wojen polsko-niemieckich lat 1003-1018. W początkowym okresie rządów Henryka II sytuacja w Rzeszy była nadal mocno niestabilna. Królewska koronacja odbyła się w wątpliwych pod względem prawnym okolicznościach, co wpływało pobudzająco na działania opozycji. Konflikt niemieckiego władcy z Bolesławem Chrobrym dał margrabiemu Marchii Północnej Henrykowi (980-1017) możliwość wszczęcia jawnego buntu przeciw Henrykowi II. Margrabia poparł w działaniach zbrojnych Bolesława Chrobrego, co w sposób naturalny powiązało podległe mu ziemie (Wschodnia Frankonia) z terenami Słowiańszczyzny. Oprócz poparcia dla polskiego władcy w wojnie z Henrykiem II margrabia Henryk oraz inni przedstawiciele rodu schweinfurckiego byli związani z procesem osiedlania Słowian na podległych sobie obszarach. Istnieje w literaturze hipoteza przytaczana przez Jerzego Strzelczyka, że fundacja kościoła w Bambergu w 1007 r. mogła zostać spowodowana chęcią utrzymania równowagi władzy na terenie Wschodniej Frankonii. Por. J. Strzelczyк: Bamberg a Polska w średniowieczu. Rocz. Hist. 1996, T. 62, s. 77. Kolejne wzmianki o relacjach polsko-bamberskich związane są z darowizną Mieszka II dla klasztoru św. Michała na Michelsbergu (informacja zawarta w nekrologu, zob. A. Gieysztor: Bamberg i Polska w XI-XII wieku. St. Źr. 1971, T. 15, s. 71-83). Kolejny poświadczony w źródłach wątek relacji między Polską a Bambergiem znajdujemy w liście Władysława Hermana skierowanym do katedry bamberskiej, datowanym na lata 1088-1095. List był prośbą o przyjęcie dwóch złotych krzyży, niesłusznie i w niejasnych okolicznościach zabranych z bamberskiego kościoła do Polski. Książę polski wykupił je i zwrócił katedrze, w zamian za co miał otrzymać wieczystą prebendę oraz modlitwę o zbawienie duszy swojej i małżonki. Więcej na temat znaczenia restytucji krzyży w polityce Władysława Hermana: R. MichaŁowski: Princeps fundator. Studium z dziejów kultury politycznej w Polsce X-XIII w. Warszawa 1993, s. 106-110, 205-207. O randze ośrodka dla kontaktów cesarstwa ze Wschodem świadczy jednak najdobitniej akcja chrystianizacyjna podjęta przez biskupa bamberskiego Ottona (11021139). Misja nawracania Pomorza podjęta przez niemieckiego duchownego w latach 1124/1125 oraz 1128 trwale zapisała się w historiografii obu państw. Przegląd źródeł dotyczących działalności misyjnej Ottona z Bambergu podaje A. Pleszczyński: Przekazy niemieckie o Polsce..., s. 132-134. W literaturze niemieckiej o roli Bambergu pisał: B. SchneIDmüLler: 1007. Die Entstehung des Bistums Bamberg. Braunschweig 2007.

33 C. Deptula: Krąg kościelny płocki w połowie XII wieku. Rocz. Hist. 1960, T. 8, s. $5-122$. 
dzy Wernerem i diecezją płocką a benedyktynami z Niemiec mogłyby również wyjaśnić, dlaczego to właśnie płocki biskup został mianowany reprezentantem Bolesława Kędzierzawego w rozmowach z Fryderykiem Barbarossą. Mogłoby to także tłumaczyć, dlaczego płocki biskup według narracji otrzymał w darze relikwie świętego, którego głównym ośrodkiem kultu był klasztor benedyktyński w Bambergu.

Opowieść o poselstwie zamyka wzmianka o wzniesieniu kościoła ku czci Henryka II. Jest to logiczne zwieńczenie struktury narracji. Nawet prowizoryczny ołtarz wykonany w miejscu objawienia uwierzytelniałby historię o świętym.

Miraculum Sancti Heinrici powstało pod koniec XII wieku, co najmniej kilkanaście lat po poselstwie Wernera do Akwizgranu. Biskup płocki miał według relacji otrzymać relikwie św. Henryka oraz inne dary, w tym relikwie burgundzkiego króla-męczennika Zygmunta, które, jak wiadomo z innych źródeł, później miał umieścić w katedrze płockiej³. Wznoszona budowla miała zostać poświęcona obydwu świętym.

$\mathrm{Z}$ tekstu miraculum dowiadujemy się jeszcze, że później na miejscu ołtarza powstał klasztor pod tym samym wezwaniem. Problemem zlokalizowania tego obiektu zajmował się Czesław Deptuła, sygnalizując, że zgodnie z informacjami zawartymi w źródle klasztor mógłby być tożsamy z klasztorem Benedyktynek w Gubiniu nad Łysą Łużycką, tudzież z klasztorem Cystersów w Dobrymługu ${ }^{35}$, z uwagi na zbliżoną lokalizację i czas funkcjonowania. Także w historiografii niemieckiej wydarzenia przedstawione $\mathrm{w}$ miraculum wiązane są z fundacją klasztoru cysterskiego

Nawet jeśli interesująca nas narracja zawiera w sobie odprysk historii o klasztorze w Dobrymługu, to w logice źródła opowieść ta ma zupełnie inne znaczenie. Miracula... są tekstem powstałym w celu wypromowania kultu Henryka II, a zatem fragment dotyczący budowy kościoła jest raczej zabiegiem, który poprzez postać biskupa Wernera miał powiązać osobę świętego cesarza z Polską.

Duże znaczenie symboliczne w opisanym fragmencie niesie ze sobą motyw kija biskupiego, którym Werner uderzył w ziemię, uzyskując bloki pod budowę. Pastorał należał do najważniejszych atrybutów władzy hierarchy kościelnego ${ }^{36}$. Baculus był również symbolem zwierzchnictwa biskupiego nad danym terytorium. Gest wykonany przez Wernera podkreślał symboliczny wymiar

34 Więcej o kulcie św. Zygmunta w katedrze płockiej: A. Nowowiejski: Płock. Monografia historyczna. Płock 1931.

${ }^{35}$ C. Deptula: Niektóre aspekty..., s. 75, także szczegółowo w: M. Lindner: Aachen Dobrilugk - Płock..., s. 140. O problemie chrystianizacji Słowian z terenów Łużyc: S. RosıK: Die Christianisierung der slawischen..., s. 57-62.

${ }^{36}$ Baculus pastoralis - więcej o nim w: W. MAISEL: Archeologia prawna Europy. Warszawa-Poznań 1989, s. 260—262. 
władztwa biskupa na terenie, gdzie rozgrywała się akcja. Cudownie uzyskany odpowiedni materiał do budowy ołtarza zostaje wydobyty dzięki uderzeniu pasterskiej laski w kopiec ziemi. Świadczy to o tym, jak ważny w narracji miraculum był problem lokalizacji miejsca związanego z Henrykiem II poza wschodnią granicą Rzeszy.

Opowieść o poselstwie Wernera kończy się stwierdzeniem, że dzięki temu dziełu ,imię Henryka również w owych ludach zaczęło zyskiwać na chwale Bożej"37. Zdanie to najwidoczniej uzasadnia przytaczanie historii w katalogu cudów Miraculum Sancti Heinrici.

Przedstawione rozważania staną się bardziej kompletne, gdy zrozumiemy, w jakich okolicznościach powstało samo źródło. Dwunastowieczna relacja o cudach Henryka II stanowiła dodatek do większego dzieła, jakim był Żywot św. Henryka autorstwa diakona bamberskiego Adalberta. Vita sancti Henrici regis została spisana $\mathrm{w} 1$. poł. XII wieku w celu rozpropagowania kultu niemieckiego władcy ${ }^{38}$. Dołączenie tekstu Miraculum Sancti Heinrici do popularnego wówczas żywota Henryka II świadczy niewątpliwie o powiązaniach jego twórcy z kręgiem duchowieństwa bamberskiego. Odwołując się do myśli Aleksandry Witkowskiej, miracula miały powstawać z zeznań świadków, a cuda opisane $\mathrm{w}$ tekstach miały być przekazem realiów, które — jak sugerowano łatwo można było sprawdzić3 ${ }^{39}$. Z tego powodu narracja miraculum osadzona jest w rzeczywistości, która mogła być znana dwunastowiecznej ludności zamieszkującej tereny Rzeszy.

Tekst Miraculum Sancti Heinrici musiał powstać po kanonizacji Henryka II w 1146 roku, a zatem w okresie rządów Fryderyka Barbarossy w Rzeszy. Choć wydaje się, że dla tego monarchy kwestie polityki wschodniej nie były szczególnie istotne, to jednakże sprawa wygnania z Polski krewnej cesarza i jej męża stanowiła poważny uszczerbek na honorze Fryderyka ${ }^{40}$. Poza tym konflikt na wschodnich granicach imperium zagrażał władzy cesarza również z tego powodu, że piastowscy juniorzy mocno i w różny sposób byli skoligaceni z panami saskimi. Zbyt mocna pozycja Piastów i zawsze kontestujących władzę dynastii zachodnioniemieckich Sasów niosła wschodnim kresom Rzeszy ryzyko destabilizacji ${ }^{41}$. Z pewnością próba zainicjowania w Polsce kultu

37 „Ultra omnes beatum Heinricum studio devociori venerabatur” — Ex Allis Miraculis..., s. 815 .

38 A. Pleszczyński: Przekazy niemieckie o Polsce..., s. 119.

39 A. Witкowska: Miracula średniowieczne. Forma przekazu i możliwości badania. St. Źr. 1977, T. 22, s. 83.

${ }^{40} \mathrm{O}$ kwestii honoru w poczynaniach tego władcy w szerokim kontekście kultury i historii epoki - K. Görich: Die Ehre Friedrich Barbarossas. Kommunikation, Konflikt und politisches Handeln im 12. Jahrhundert. Darmstadt 2001.

${ }^{41}$ R. Kötzschke, H. Kretzschmar: Sächsische Geschichte. Werden und Wandlungen eines Deutsches Stammes und seiner Heimat im Rahmen der Deutschen Geschichte. Frankfurt am Main 1965. 
Henryka II stanowiła ważny aspekt wysiłków podejmowanych przez Fryderyka Barbarossę, których celem było utrzymanie pokoju i wpływów cesarza nie tylko na wschodzie Rzeszy, ale również w Polsce. Tak przynajmniej sprawa wygląda w świetle tekstu Żywota św. Henryka oraz Miracula... Nie bez przyczyny akcentowano $\mathrm{w}$ tych przekazach przekonanie o tym, że święty cesarz podbił Polskę zbrojnie, wspomagany przez Niebiosa, później zaś Polacy bezprawnie i bezbożnie — jak sugeruje źródło — zerwali zależność od cesarstwa.

W obliczu tych faktów tym potrzebniejsza i bardziej uzasadniona wydawała się inicjatywa Fryderyka Barbarossy zaszczepienia kultu Henryka II nie tylko wśród Słowian podległych mu bezpośrednio, ale i w Polsce, zależnej jak mniemano - pośrednio. Wysiłki te okazały się bezowocne: wiemy o nich właściwie jedynie $\mathrm{z}$ tekstu miraculum. Tym cenniejsze są jednak zawarte o nich w tym źródle wiadomości, ponieważ stanowią bardzo ciekawy i istotny przyczynek do poznania dziejów relacji Polski i Rzeszy w średniowieczu oraz w ogóle do badań nad umysłowością dwunastowiecznych elit niemieckich i ich postrzegania kraju Piastów.

\section{Bibliografia}

\section{Źródla drukowane}

AnOnim tZw. Gall: Kronika polska. Przekł., oprac., wstępem i przypisami opatrzył M. PleZIA. Przeł. R. Grodecki. Wrocław 1982.

Biblia Sacra. Vulgate Editionis. Ed. A. Colunga, L. Turado. Madrid 1995.

Die Vita sancti Heinrici regis et confessoris und ihre Bearbeitung durch den Bamberger Diakon Adelbert. Ed. M. StumpF. In: Monumenta Germaniae Historica. Scriptores rerum Germanicarum. Hannover 1999.

Ex Allis Miraculis Sancti Henrici, Annales, Chronica et historiae aevi Carolini et Saxonici. In: Monumenta Germaniae Historica. Seria Scriptores. T. 4. Hannoverae 1841.

Powieść minionych lat. Charakterystyka historycznoliteracka. Przeł. F. SiELICKI. Kraków 1968.

Opracowania

Biniaś-SzKopeK M.: Bolesław Kędzierzawy, książę Mazowsza i princeps. Poznań 2009.

DePtula C.: Krag kościelny płocki w połowie XII wieku. „Roczniki Historyczne” 1960, T. 8. 
DePtuŁa C.: Niektóre aspekty stosunków polsko-niemieckich w XII wieku. W: Polska w Europie. Studia historyczne. Red. H. ZIns. Lublin 1968.

Deptula C.: Werner (zm. 1172) biskup Ptocka. W: Hagiografia polska. Red. R. Gustaw. T. 2. Poznań 1971.

Deptula C., Witkowska A.: Wzorce ideowe zachowań ludzkich. W: Polska zjednoczona i dzielnicowa. Red. A. GieyszTor. Warszawa 1972.

Gieysztor A.: Bamberg i Polska w XI-XII wieku. „Studia Źródłoznawcze” 1971, T. 15.

GöRICH K.: Die Ehre Friedrich Barbarossas. Kommunikation, Konflikt und politisches Handeln im 12. Jahrhundert. Darmstadt 2001.

GrabsKi A.F.: Polska w opiniach obcych X-XIII wieku. Warszawa 1964.

Guriewicz A.: Kultura i społeczeństwo średniowiecznej Europy. Warszawa 1997.

Guriewicz A.: Problemy średniowiecznej kultury ludowej. Warszawa 1987.

Hoffmann E.: Die heiligen Könige bei den Angelsachsen und den skandinavischen Völkern. Königsheiliger und Königshaus. Neumünster 1975.

Klinczay G.: Holy Rulers and Blessed Princesses. Dynastic Cults in Medieval Central Europe. Cambridge 2002.

Kötzschke R., Kretzschmar H.: Sächsische Geschichte. Werden und Wandlungen eines Deutsches Stammes und seiner Heimat im Rahmen der Deutschen Geschichte. Frankfurt am Main 1965.

Lindner M.: Aachen - Dobrilugk — Plock. Markgraf Dietrich von der Ostmark, Bischof Werner von Płock und die Anfänge des Zisterzienserklosters Dobrilugk. In: Die Nieder- und Oberlausitz - Konturen einer Integrationslandschaft. Bd. 1: Mittelalter. Hrsg. H.-D. Heimann, K. Neitmann, U. Tresp. Berlin 2013.

Maisel W.: Archeologia prawna Europy. Warszawa-Poznań 1989.

Malcolm G.: The Holy Grail: Its Origins, Secrets \& Meaning Revealed. London 1994.

Michalowski R.: Klasztor prywatny w Niemczech IX-XII w. jako fakt religijny i spoleczny. (Wybrane zagadnienia). W: Polska - Niemcy w średniowieczu. Materiaty z konferencji naukowej zorganizowanej przez Instytut Historii UAM $w$ dniach 14-16 XI 1983 roku. Poznań 1986.

Michatowski R.: Princeps fundator. Studium z dziejów kultury politycznej w Polsce XXIII w. Warszawa 1993.

Nowowiejski A.: Płock. Monografia historyczna. Płock 1931.

Petersohn J.: Kaisertum und Kultakt in der Stauferzeit. In: Politik und Heiligenverehrung im Hochmittelalter. Hrsg. J. Petersohn. Sigmaringen 1994.

PleszCZyński A.: Niemcy wobec pierwszej monarchii piastowskiej (963-1034). Narodziny stereotypu. Postrzeganie i cywilizacyjna klasyfikacja władców Polski i ich kraju. Lublin 2008.

PleszCZyński A.: Przekazy niemieckie o Polsce i jej mieszkańcach w okresie panowania Piastów. Lublin 2016.

Pleszczyński A., Sobiesiak J., Szejgiec K., Tomaszek M., Tyszka P.: Historia communitatem facit. Struktura narracji tworzacych tożsamości grupowe w średniowieczu. Wrocław 2016.

Rosik S.: Conversio gentis Pomeranorum. Studium świadectwa o wydarzeniu (XII wiek). Wrocław 2010.

Rosik S.: Die Christianisierung der slawischen Stämme auf dem heutigen Gebiet der Lausitz. In: Die Nieder- und Oberlausitz - Konturen einer Integrationslanschaft. Bd. 1: Mittelalter. Hrsg. H.-D. Heimann, K. Neitmann, U. Tresp. Berlin 2013.

SchneIdmüLler B.: 1007. Die Entstehung des Bistums Bamberg. Braunschweig 2007.

STARnawska M.: Świętych życie po życiu. Relikwie w kulturze religijnej na ziemiach polskich $w$ średniowieczu. Warszawa 2008. 
Strzelczyk J.: Bamberg a Polska w średniowieczu. „Roczniki Historyczne” 1996, T. 62.

Trawkowski S.: Kaźń kasztelana Bolesty (1170) w tradycji płockiej. „Studia Źródłoznawcze” 1969, T. 14.

Trawkowski S.: Taberny płockie na przełomie XI i XII wieku. „Przegląd Historyczny” 1962, T. 53 , z. $3-4$.

WeINfurter S.: Heinrich II. (1002-1024). Herrscher am Ende der Zeiten. Regensburg 1999.

Wiszewski P.: Struktura, fabuła i historia. Wokół opowieści o odzyskaniu wzroku przez Mieszka. „Biuletyn Polskiej Misji Historycznej” 2009, T. 5.

Witkowska A.: Miracula średniowieczne. Forma przekazu i możliwości badania. „Studia Źródłoznawcze" 1977, T. 22.

Zimmermann G.: Karlskanonisation und Heinrichsmirakulum. Ein Reliquienzug der Barbarossazeit von Aachen über Dobrelug/Lausitz nach Ptock. „Bericht des Historischen Vereins von Bamberg“" 1966, Vol. 102.

Marta Nowak

The Holy Emperor and the Slavic Peoples The Ideological Significance of the Polish Presence in Miracula Sancti Heinrici

Summary

The article analyzes a fragment of the $12^{\text {th }}$-century account of the miracles of Henry II, created for the purposes of promoting the cult of this Holy German Emperor. The article, therefore, discusses the narrative threads regarding the perception of the Slavic peoples by $12^{\text {th }}$-century Bamberg clergy, the collective authors of Miracula Sancti Heinrici, with particular emphasis placed upon the conception of promoting the cult of Henry II beyond the boundaries of the Reich and transplanting it to Poland. To that end, the article analyzes two excerpts from the manuscript, which document the intentions of transplanting the cult of the Holy Emperor to the territory of the Slavic lands, and Poland in particular. The first of those excerpts concerns an account of the miraculous healing of a Slavic man in Merseburg, while the second recounts a vision of Werner, the Bishop of Płock. Therefore, the article considers first and foremost the ideological meaning of the discussed examples excerpted from the source text, including the historical context of its creation.

Key words: Saint Henry II, Slavic peoples, Poland, Bamberg 


\section{Marta Nowak}

Der heilige Kaiser und Slawen

Zur ideologischen Bedeutung des polnischen Motivs

in Leben und Wunder des Heiligen Heinrichs

Zusammenfassung

Die Arbeit setzt sich zum Ziel, eine Passage aus dem Bericht des 12. Jahrhunderts über die Wunder von Heinrich II. dem Heiligen zu analysieren. Der besprochene Bericht entstand zum Zwecke der Förderung des Kultes des deutschen Herrschers. Im Artikel werden solche Handlungsstränge behandelt, die mit der Wahrnehmung von den Slawen und den slawischen Ländern durch den Bamberger Klerus des 12. Jahrhunderts — den Kollektivautor des Textes Miracula Sancti Heinrici — verbunden sind. Besonderes Augenmerk richtet sich auf die Fragen, die mit dem Konzept zusammenhängen, den Kult von Heinrich II. außerhalb der Reichsostgrenzen zu fördern und ihn in Polen einzuimpfen. Im Artikel werden zwei Passagen der Quelle analysiert, die die Ideen dokumentieren, den Kult des heiligen Kaisers auf die slawischen Länder und insbesondere auf Polen zu übertragen. In der einen Passage wird das Wunder der Heilung eines Slawen aus Merseburg beschrieben, die andere handelt von der Vision des Bischofs Werner von Płock. Die Überlegungen betreffen die ideologische Aussagekraft der genannten Quellenbeispiele unter Berücksichtigung des historischen Kontextes der Entstehung von miraculum.

Schlüsselwörter: Heinrich II. der Heilige, Slawen, Polen, Bamberg 